\title{
Transformation of Ulos as Creative Textiles For Fashion Design Learning
}

\author{
Nining Tristantie \\ Universitas Negeri Medan \\ Fakultas Teknik \\ Medan, Indonesia \\ n1n4tristan@gmail.com
}

\begin{abstract}
Qualified education is one which is able to reflect the globalization movement dinamically. Clothing Education and globalization should provide an implication to the economy accelaration which needs creative effort to drive either local or international market through learning which should contain local genius. One of the local genius departing from cultural artifacts as a solid object is the usage of traditional textile from the Bataknese, North Sumatra, namely Ulos. Based on literature studies, Ulos as traditional textile can be adapted for design ideas which finally could be transformed as a number of creative contemporary objects. The development starts from motifs on Ulos which is cultivated as printing textile or redefining about character of the base material with the traditional weaving technology as well as weaving machine. Through exploration of local content departs from the cultural richness which inspires in producing a number of creative textile which finally transferred as fashion design learning.
\end{abstract}

Keywords-Globalization, Transformation, Fashion, Ulos, Designing.

\section{INTRODUCTION}

Indonesia has a very multicultural diversity. This makes Indonesia has a rich variety of cultural artifacts. One of which is traditional textile that is very prominent with various production techniques. Production techniques that have been done as an inheritance in this community makes the character of traditional textiles as a differentiator from one area to another. Differences can be seen from designs and have symbolic meaning. Over centuries textiles of this tradition have played an important role in inter island trade and international trade. (Kahdar, Kahfiati et all; 2010).

As a nation that has a diversity of cultures, it needs challenges to be faced by the world of education to increase human resources that can bridge the needs of the fashion industry by staying based on local values. The fashion industry of the future requires unlimited creativity and innovation as a strategy to survive in globalization. The efforts made by the Chinese fashion industry which emphasizes on creative design and technological innovation. China uses these two things by likening them as two wheels that can pushed strongly to the forward transition to the field of fashion design that becomes the sphere of creative fashion industry.(Tian, Bingqiang, $\mathrm{Hu}$, Shouzhong.2016) These problems are also in line with the reality faced by the creative economy that exists in Indonesia, based on Department of Trade on the description of the Creative Industry of 2009-2015 that the largest contribution of GDP (Gross Domestic Product) to Creative Industries is in the fashion field of 43.71 Percent based on constant prices. (2008). This value is growing every year. Although it continues to show an increase, but this condition doesn't actually touch the aspect of individual Indonesian creativity. This Assumption is based on the number of potentials that have not been explored, especially from the originality of design departing from the cultural richness in Indonesia. The implication of this problem is the need for quality of human resources for the improvement of creativity and innovation that depart from the education especially for the development of design.

The education of Clothing is expected to anticipate the movement of globalization and develop many lessons that are full of local cultural values. One of them is ulos. Ulos has a motifs tradition that contains many philosophical meanings. A piece of cloth has a different function in accordance with the existing motifs on the Ulos. The study of batik aesthetic of batak tradition in contemporary context is important to be done as a reflection to arouse national pride of society including young generation especially the student of clothing education. Lifting traditional textiles as a learning, is an opportunity to introduce the outside world of the wisdom of cultural values in a global context through fashion design by digging and lifting the character in the substance of learning Fashion Design. Learning clothing design is expected to have the character of local wisdom, which is able to explore elements of tradition to be presented in the concept of the Present. But in the process there are something to be noticed, especially in digging traditional textiles such as Ulos.

\section{THE EXOTIC OF ULOS AND PYLOSOPHY}

Exploring how Ulos early presence is to study it historically. Ulos has the meaning of 'selimut (blanket)' that is able to provide warmth to its users. The blanket interpretation here is not as a denotative warmer. Ulos connotatively means the warmth of relationships, by giving Ulos to someone by 'blanketing' or attaching or 'pinning' through traditional rituals. 
Ulos as it is known as a traditional object that has a philosophy not just a woven fabric. Because in the Batak community, Ulos has a symbolic meaning. This is because the motifs contained in the weaving is an expression of salvation for a deep hope for 'the users'. It can be seen how the role of Ulos in Batak daily life. Ulos has a very central role, representing the life phase of the community. In this respect Ulos as a form of reverence and sacred has become part of a traditional ceremony by giving it to someone who is deemed worthy and worthy of receiving it. This gift is based on important life events such as marriage, birth, or death. This is done for generations by the ancestors of the Batak tribe.

Putting Ulos on the shoulder in the tradition of so-called 'mangulosi' marriage uses special Ulos . Ulos Ragiidup motif is used in Mangulosi ceremony for the bride to bring together the bride and groom. Mangulosi ceremony for the parents of the bridegroom by the bride's parents using Ulos Pansamot as an expression of welcoming family of women. Similarly, when the mangulosi event of death, moving house or the birth should use Ulos with different motifs. Ulos is used differently depending on the motif of Ulos. This proves that Ulos has become part of the human child as sacred symbols. It is believed that wherever Batak traditions are, mangulosi will consistently run.

The expression which says that the use of Ulos is basely used during the activities of traditional traditions has been fully accepted reality as Ulos has its contextual meaning that lies precisely on its motifs. But it does not mean that Ulos can be worn just for a mean while. In traditional textiles there is a symbolic space that requires interpretation to be able to process elements existing on the custom fabric in order to link between past and present traditions. Therefore, the interpretation of Ulos as a textile used as fashion textile requires an in-depth study to be presented as a new form and a part of contemporary design. Traditional textile processing such as Ulos must be addressed wisely while maintaining cultural wisdom. This understanding needs to be studied in the learning of Fashion Education. This is important for the young generation, especially students not only be able to understand the philosophy of textiles culture but also to translate them as national identity that could contend in global industry.

\section{THE TRADITION THEME FOR FASHION TEXTILES}

Ulos has its own exotica. Although using a limited color, Ulos has a motive character that distinguishes it from other textiles in Indonesia. Historically weaving Ulos that exists today is an ancestral activity performed by the women, worked after a crop or in leisure time. History of Batak textiles is the history of Batak women. In the writings of Niessen, (2009) Ulos woven by women and is identified as the center of the cosmos of the life of Batak women. Anthropological and social studies explain if weaving activities and women show 'joy'. Observing how the fabric of yarn woven into a cloth called Ulos has a profound philosophical meaning. Ulos has the meaning of 'spirit' and 'soul' on a fabric that has a symbolic meaning, debating always come up when it is being made as a fashion textile. The fashion industry in this country is in a dynamic and promising condition. Building upon the needs of a fashion industry posits an increasingly market orientation accompanied with an increasingly economic, political and cultural climate demands for a more individualized lifestyle. At this level, fashion needs not only at the level of essence but mixed with multiple aspects. This is one of the features of urban society that is always looking for new designs that are more in line with contemporary society. (Chunyan, QIU and Yue, HU.2014). The acceleration of science and technology has influenced the form of design and the art of dressing. It brings new changes and meanings to the forms of clothing. Anticipating the acceleration in fashion that is supported by the latest technology (high-tech) and modern fashion has fused boundary between multidisciplinary leading technology with the development of clothing art. This provides an awareness for the designers that the future of the latest clothing technology will 'live' in imagination and real science fiction that departs from traditional styles to the direction of clever designing of clothing. Development of innovative materials, Development of Novelty Patterns of design, Sustainable Design of Clothing Art, The use of Eco Friendly Design are some signs of these traits.

Various attempts are made by designers to display personalized clothing styles by exploring various ideas. The concept of fashion with the theme of tradition gives fresh air for the fashion industry homeland that is seeking local identity to be presented with a global style. The cutting-edge style raised by top designers is an inspiration to consumers with more affordable options. This phenomenon is also followed by local fashion players using Ulos as part of the creative process.

Not only for the observers of Batak Culture society, the debate surrounding the use of Ulos as a fashion material, still raises a different opinion among the designers who raised the cloth as the idea in the work. There are opinions allowing the direct use of traditional textiles by combining them with other materials. (Interview with Edward Hutabarat, 2015). While other designers do not justify using the material except on some permissible motif for considering that have symbolic meaning that accompanies it. (Sihombing, 2017). This condition often leads to debate on how to interpret the Ulos in the fashion industry. Discussion with designer Merdi Sihombing revealed that Ulos is not necessarily a fashion product. The flexibility of insight and interpretation of the object of custom is a necessity. As it is in his work entitled 'índigo', which presents a collection that departs on the depth of its interpretation of weaving in Indonesia such as Ulos and Songket.

For the Batak community, Fashion that uses Ulos as a material and combines it with modern textiles is still reluctant to use as most people are still bound by custom. It will be different if the material is interpreted. The discussion here lies not in the question whether the Batak tribe wants to use it or does not. However, the focus of discussion is the need for intelligent and critical efforts in processing traditional textiles and adapting them into 'other textiles' which have the form of transformation from the initial form. It means that fashion in the context of cultural heritage must be maintained, passed down from generation to generation on how to maintain symbolic value in order to become the character of the nation. 
It does not mean that fashion creators will not work or limit their imaginative thinking through Ulos. The existence of this problematic study requires an understanding of Ulos and its surrounding cultural environment. In the end, fashion creators are required to find works that are noble and giving prestige from the outside world. This is in line with the Strategic Plan of Culture (Renstra Ditjenbud, 2013) embodied in the vision of kemendikbud 2025 on the implementation of culture and its development in education along with the appreciation and creativity of the community that all efforts undertaken is to prosper the nation.

\section{INTERPRETATION ON FASHION DESIGN}

Weaving tradition is still carried on in certain areas in Batak land currently with market orientation not only for the needs of custom but also from the fashion aspect. Ulos has evolved into a fabric that has an interpretation of the trend of demands as a fashion product. This is one effort made by the local government Ulos cloth is not left by the next generation as well as not recognized by other countries. The Ministry of Industry also intervened by conducting coaching for Ulos weaving craftsmen in North Sumatra as an effort to develop a national woven cloth to preserve the cultural heritage of Indonesia. (2016). As addition, the things that need to be considered in the development of fashion with Ulos fabrics. "So, the motive that is displayed is not the Ulos motive used in various ritual ceremonies so as not to damage the sacred concept of Ulos itself," he said. Ulos is still used as a cloth with a symbolic function in the Batak community order, as well as the activities of Mangulosi which symbolize the giving of blessing, compassion, hope, and other goodness.

Ulos weave today has grown by providing a rich variant of cloth both in terms of color and motif with songket design. Songket of Batak is known today is widely marketed in traditional markets in the city of Medan. This songket is an interpretation of Ulos used as fashion textiles, using a combination of from some Ulos weaves.

Ulos with original color character has its own value. For designers like Ghea panggabean and Ida Royani following Merdi Sihombing is a designer who intelligently interprets how Ulos could be used as a design idea that posses Indonesian character that comes from Batak textile tradition. Understanding how the philosophy behind motifs in ulos weaving by making it a direct clothing or combining it. (Interview with Merdi Sihombing 26 Apr2017). The interpretation of Ulos is presented with a touch of modernity, adapted with traditional weaving to retain the character of the technology of traditional Looms (ATBM) that departs from the traditions of the local community. In the coloring process, Merdi uses natural colors. The result is a textile craft that characterizes the personal character of the designer who still has elements of tradition. Similarly, songket originating from West Sumatera, known as Pande Sikek, was successfully adapted into contemporary textiles with traditional looms technology using natural coloring. In Ida Royani's clothing design adopts the idea of Ulos weaving by transforming the textile into printing. The stiff character of Ulos weft succeeds gracefully on the design character above the floating chiffon, using a combination of ethnic colors.

\section{TRANSFORMATION OF TRADITIONAL TEXTILE TECHNOLOGY FOR LEARNING CLOTHING DESIGN}

Globalization is an economic engineering that makes life of human is open and the human openness is the key. Quality education is the motto of globalization. (Munadi, 2008). The change of economic structure based on agriculture to the industry-based economy changed the way of life and thinking of the nation. This reality can be observed how the global community order has done through it and is evidenced by the creative economy began in the 1990 s that is driven by the industrial sector called the Creative Industry. (2008) The increasing of modern industry is requiring more technical personnel at the intermediate level as well as professional technical personnel. Education and training need to be prepared in tailoring its programs with rapid technological advances. This is in line with the demand of creative industries that require creativity and innovation in developing fashion design and craft based on local wisdom. Daniel L.Pink (2008) reveals that in the era of creativity, if you want to go forward, technological capabilities (high-tech) needs to be complemented with the desire to achieve the level of "high concept" and "high touch". High Concept is the ability to create artistic and emotional beauty, recognize patterns and opportunities, create beautiful narratives and produce discoveries that have not been realized by others. High touch is the ability to empathize, understand the essence of human interaction, and find the its primary meaning.

Fashion Education plays a role to create human resources that can essentially have life skills. Referring to the principle of Prosser C. A. (1949) on vocational education that matches the reality of the workplace with the availability of learning to provide opportunities to learners have the knowledge and skills. In this context, Clothing Education Department is required to follow the development of global fashion market which emphasizes on creativity and innovation in the field of fashion design that depart from traditional textile that is Ulos.

The importance of learning Clothing design as a vocational education needs to be transformed with technological knowledge. The approach of technology in question is how tradition can produce novelty. The cultivation of an understanding of traditional textiles includes historical, philosophical and symbolic aspects. This learning has sustainability at the interpretive level of ideas development on traditional weaving. The development of ideas can be attempted to touch and consider global issues in the fashion sector such as cultural issues, green textiles or sustainable textile. (Antti, 2014).

Technological approach can help learners in bridging the idea of imagination and the idea of reality to produce variants of creative design that has not been realized by others that ultimately able to produce originality in the work. In the context of traditional weaving studies, the idea that departs from Ulos weave can produce the following innovations:

1) Adaptation Traditional on Ulos weaves for a number of creative fashion developed through such Hand Embroidery and Machine Embroidery 
2) Develop the weaving motif through the technique of dozen threads and feed to produce new motif patterns using hand weaving. The use of this technology strongly supports the concept of sustainable textiles, in addition its aims to meet design needs and made based on aesthetic considerations. The interpretation of Ulos traditional weaving can be developed into 'green textile' by using environmentally friendly materials by interpreting mainly from the use of natural yarn and coloring materials.

3) Developing traditional weaving using machines to produce affordable textiles.

4) Develop new textile with textile printing technology to produce new motifs and variants.

\section{SUMMARY}

Creative economy has encouraged the domestic industry especially in the field of fashion to continue to work to improve creativity and innovation in the field of industry. The demand to compete in the Global Market is to explore the tradition culture that is used as the identity of the nation's work. Fashion Education plays an important role in producing human resources that are able to support the creative industry based on local wisdom. Fashion Design emphasizes the importance of innovating for traditional textile learning, Ulos. Ulos has power as a style that has an original character. The use of ideas that depart from Ulos as a fashion material can be done if it can understand the essence of the textile tradition. The transformation of technological concepts in traditional textiles such as Ulos weave can be done with interpretive approach based on global market orientation.

\section{REFERENCES}

[1] Ainamo, Antti."Rethinking Textile Fashion".New Materiality. Smart Products, and Upcycling. Swedish Desgn Research Journal. p.53-60. 2014]

[2] Munadi, Sudji. Transformasi Teknologi pada Pendidikan Kejuruan. Seminar Internasional Optimasi Pendidikan Kejuruan dalam Pembangunan SDM Nasional dan Konvensi Nasional Ke IV APTEKINDO 3 - 6 Juni. 2008.Fakultas Teknik Universitas Negeri Padang

[3] Kahdar, Kahfiati et all.. "Tenun. Handwoven Textiles of Indonesia". Cita Tenun Indonesia. 2010

[4] Niessen, Sandra. "Legacy in Cloth. Batak textiles of Indonesia". Kitlv Press Leiden. p.21, 2009].

[5] Studi Industri Kreatif. "Rencana Pengembangan Ekonomi Kreatif Indonesia 2009-2015".Departemen Perdagangan RI. 2008.

[6] Prosser, C.A.\& Qigley, T.H., 1949.Vocational Education in a Democracy.American Technical Society, Chicago Illonois.

[7] Chunyan, QIU and Yue, HU. "The Research and Development of the Future Fashion Design". American International Journal of Contemporary Research. Vol. 4, No. 12; December 2014.

[8] _.2016. Kemenprin Lakukan Pembinaan Bagi Pengrajin Tenun Ulos.20 Oktober. bisnisreview.com/review-4429--kemenprinlakukan-pembinaan-ba...-

[9] __.2010-2014. Renstra Kebudayaan Visi, Misi, tujuan dan Sasaran bidang kebudayaanDitjen...kebudayaan.kemdikbud.go.id?,,,?Resntra-Ditjenbud07.01.2013b.p...Acces 11 Dec 2016. 